\title{
La grammaire des sexes : éléments pour une tradition, et sa réception dans As You Like It
}

Jean-Pascal Pouzet

\section{(2) OpenEdition}

\section{Journals}

Édition électronique

URL : http://journals.openedition.org/shakespeare/934

DOI : 10.4000/shakespeare.934

ISSN : 2271-6424

Éditeur

Société Française Shakespeare

Édition imprimée

Date de publication : 1 novembre 2002

Pagination : 165-202

Référence électronique

Jean-Pascal Pouzet, «La grammaire des sexes : éléments pour une tradition, et sa réception dans As You Like It ", Actes des congrès de la Société française Shakespeare [En ligne], 19 | 2002, mis en ligne le

01 novembre 2007, consulté le 01 mai 2019. URL : http://journals.openedition.org/shakespeare/934 DOI : 10.4000/shakespeare.934 
Le statut du De Planctu est-il toujours d'être second dans l'Angleterre de la Renaissance ? Cet arrière-plan est-il malgré tout $a$ contrario le signe d'une dissémination profonde ? Quoi qu'il en soit, entre $A Y L I$ et le De Planctu, beaucoup de rapprochements me paraissent troublants, dans l'architecture d'ensemble comme dans le détail, même si rien n'indique à coup sûr que Shakespeare ait connu directement l'œuvre, bien que cela soit loin d'être impossible. Mentionnons ici, à titre d'invitation à recherche, qu'une possibilité supplémentaire de transmission indirecte d'Alain de Lille (son Anticlaudianus plus que son De Planctu ?) pourrait être intervenue auprès de Shakespeare par l'intermédiaire du Zodiacus vitae du poète italien Marcellus Palingenius, dont la traduction anglaise complète par Barnaby Googe fut publiée en 1565 et la version latine originale imprimée en Angleterre en 1569, et dont T. W. Baldwin et J.W. Binns rappellent qu'il inspira au dramaturge, entre autres passages, la célèbre tirade du theatrum mundi placée dans la bouche de Jaques en II.7.139-66 ${ }^{80}$. Quoi qu'il en soit, les parentés de thèmes et de motifs abondent: le déclin du monde et sa tentative de régénérescence autoritaire par une intervention finale, une falsigraphie généralisée qui se dit par la grammaire (prédications et copulations ambiguës, l'actif transformé en passif...) et se lit jusque dans les moindres détails de l'écriture et de sa matérialité, avec le commentaire sur les vers boiteux, la poésie comme risque de feinte, les ambiguïtés grammaticales, solécismes, les couleurs, leur équilibre ou leur rupture... Je ne pourrai ici mettre de point final aux convergences, et ce qui suit n'a l'ambition que d'évoquer certaines d'entre elles ${ }^{81}$.

Tout comme dans le De Planctu (par exemple dans l'extrait célèbre du Metrum I cité plus haut), plusieurs passages d'AYLI reflètent ainsi des confusions grammaticales fort dérangeantes. En V.2.78-97, la diathèse passive du verbe «make» employé par Silvius dans trois répliques parfaitement isomorphes, qui développent sa réponse à la question de Phoebe sur ce que c'est qu'aimer, envahit la relation prédicative au point de générer pas moins de douze reprises elliptiques (trois tags «and so am I», eux-mêmes repris en écho à chaque fois par les six «and I» et les trois «and so am I» de Phoebe, Orlando et Rosalind) et de menacer l'agentivité des personnages :

Pho. Good shepherd, tell this youth [Rosalind-Ganymede] what 'tis to love.

Silv. It is to be all made of [...], and so am I for Phoebe. 
Pho. And I for Ganymede.

Orl. And I for Rosalind.

Ros. And I for no woman.

La syntaxe, semble-t-il, ne saurait mieux mimer les dangereuses liaisons syntaxiques entre les personnages. En V.4.106-10, le chant d'Hymen complique encore les prédications, alors même qu'il est censé les redresser :

Hym. Good Duke, receive thy daughter;

Hymen from heaven brought her,

Yea, brought her hither,

That thou mightst join her [F his] hand with his

Whose heart within his bosom is.

Que l'on suive la lectio difficilior du Premier Folio (F) de 1623 (qui donne his au vers 109), ou celle, apparemment majoritaire, du Troisième Folio de 1663 (qui offre hir, pour her) ${ }^{82}$, la relation prédicative soustendue par ces vers donne à entendre une curieuse relation - un véritable "problème herméneutique» ${ }^{83}$. Soit her manifeste une iunctura recta entre deux pronoms de genre différent («her hand with his»), soit his tire l'intervention d'Hymen du côté d'une espèce d'homosocialité dramatique, qui va unir par les liens sacrés du mariage deux his — et cette seconde lecture, qui équivaudrait à un solécisme caractérisé dans le De Planctu ${ }^{84}$, recouperait tout à fait la thèse de Louis A. Montrose, pour qui le processus qui traverșe la pièce correspond avant tout à la réunification entre Orlando et les autres figures masculines (frère, père), sans pour autant qu'il soit jamais question dans son approche de Rosalind sous les espèces de Ganymede ${ }^{85}$. Quoi qu'il en soit, l'antécédent de la relative introduite par «whose heart», et par conséquent le référent de his au vers 110 , demeurent éternellement ambigus. S'il en était besoin, les copules grammaticales aux arguments mal définis ${ }^{86}$ doublent discrètement sur le registre de la grammaire les étourdissantes copulations qu'annoncent les différentes unions prononcées par Hymen (V.4.120-41) ${ }^{87}$.

À ce titre, l'écriture dramatique désoriente les repères ordinaires - ou plutôt, pour s'y retrouver, il faut accepter d'exhiber la part de fausseté qu'elle contient, tout comme la poésie. Elle est à part entière une falsigraphie, pour reprendre un terme que l'on trouve sous la plume d'Alain : 
haute condition, a recours à un métaplasme des plus irréguliers lorsqu'elle tourne les règles de Vénus, en commettant des barbarismes dans la construction des genres. C'est ainsi que l'homme, devenu Tirésias par l'effet d'une Vénus perverse, bouleverse la relation droite par ses agencements. Se détournant ainsi de l'orthographe de Vénus, il est convaincu d'être un falsigraphe sophiste. ${ }^{88}$

Entailler, faire des vers boiteux, perdre ses couleurs de rhétorique ${ }^{89} \ldots$ les figures de la falsigraphie vénérienne n'en finissent pas de traverser la pièce, comme autant de moments qui déclinent la déclinaison, décrivent dans toute sa matérialité l'errance viciée de l'écriture tombée, de sa syntaxe lapsaire. De manière troublante, chacun de ces traits peut trouver un ancêtre dans le De Planctu ; je n'aurai le loisir que d'en évoquer certains, parmi une multitude - certains de ceux qui prêtent à des références volontiers métadramatiques ${ }^{90}$.

À l'instar du De Planctu, il est ainsi fructueux de lire AYLI comme un prosimètre, avec des parties alternées de prose rythmée et de vers dont les poèmes d'Orlando et les chansons. La souplesse stylistique du prosimètre porte à merveille la confusion et la conflation des genres textuels et sexuels, dans une pièce dont la «seule livrée» est la «bigarrure», selon la formule triomphale de Jaques en II.7.34. La théâtralité implicite qui anime les débats des allégories fragiles du De Planctu trouverait une espèce de débouché prosodique dans un prosimètre porté à la scène, dont les allusions à la fabrique des répliques tournent à l'auto-référentialité la plus suspecte. Ainsi en III.2.158-65, Celia et Rosalind commentent les claudications hypermétriques d'Orlando :

Cel. Did thou hear these verses?

Ros. O yes, I heard them all, and more, too, for some of them had in them more feet than the verses would bear.

Cel. That's no matter; the feet might bear the verses.

Ros. Ay, but the feet were lame, and could not bear themselves without the verse, and therefore stood lamely in the verse.

C'est un échange que je ne peux m'empêcher de lire sans me souvenir de $œ$ 
qu'écrit Alain de Lille dans son Metrum ${ }^{91}$ :

Sic pede dactilico Veneris male iambicat usus

In quo non patitur sillaba longa breuem.

Les deux œuvres font des éléments de versification un motif de discours sur les implications ontologiques de la prosodie, car les imperfections naturelles se reflètent dans les déviances par rapport à elle. Dans $A Y L I$, l'importance conférée au vers dans ce qu'il a de plus matériel, qui rejoint la thématique de la poésie comme feinte, me semble ainsi devoir tout autant son origine à des traités tels que The Arte of English Poesie de George Puttenham (1589) qu'à une «fiction» comme le De Planctu.

S'il s'agit des couleurs, les textes se rapprochent encore. AYLI tout comme le De Planctu porte une grande attention aux couleurs qui composent la palette des visages. On pourra lire en parallèle la description du visage de Nature par le poète,

Ses dents, par une certaine unité de leur couleur, avaient l'apparence de l'ivoire. Le feu pourpre de ses joues, allumé par la teinté des roses, par cette douce flamme donnait un air aimable à sa figure. Et par l'effet de sa candeur gracieuse, le rouge de son visage marié au blanc de la mousseline [du voile qui lui couvrait le visage], faisaient un mélange harmonieux. ${ }^{92}$

et l'amoureux blason que Phoebe donne de Ganymede en III.5.121-4 :

Phoe. [...] There was a pretty redness in his lip,

A little riper and more lusty red

Than that mixed in his cheek. 'Twas just the difference

Betwixt the constant red and mingled damask.

Sans doute en vertu du processus de transfert qu'évoque Amiens ${ }^{93}$, cette vision colorée trouve également sa glose au plan structurel, littéralisant le trope des couleurs de la passion et de la rhétorique. En III.4.47-9, le berger Corin évoque ainsi 
pour signifier à Rosalind-Ganymede et Celia-Aliena l'échange entre Silvius et Phoebe donné sur scène en III.5. Si l'on en croit Nature, dans le portrait qu'elle dresse dans la Prosa V de la dégénerescence de Vénus, juste avant d'évoquer la conception de Jocus (produit de son union avec Antigamus), déstructuration grammaticale, décoloration physique et tranfert rhétorique vont de pair :

[...] se coupant des constructions de la grammaire, se détournant les conversions de la dialectique, se décolorant au contact des couleurs de la rhétorique, elle transmuait son art en figure, sa figure en vice $[\ldots]{ }^{94}$

Par conséquent, perdre ses couleurs revient dans les deux textes à écrire $a u$ noir. Le commentaire entre Rosalind-Ganymede et Silvius sur la main brune et rude ${ }^{95}$, l'écriture et le style par lesquels Phoebe se déclare à Ganymede dans une lettre, va jusqu'au dénigrement :

Ros. I say she never did invent this letter.

This is a man's invention, and his hand. Silv. Sure, it is hers.

Ros. [...] Women's gentle brain

Could not drop forth [...]

Such Ethiop words, blacker in their effect Than in their countenance [...]. ${ }^{96}$

L'ambiguïté des référents des pronoms mis en joute s'adjoint une fois encore à la trame du propos. Chez Alain, un vers du passage du Metrum I cité plus haut, «femina uir factus sexus denigrat honorem», établit clairement le double sens de cette opération de mise au noir : noircir sa réputation et dénigrer ses attributs physiologiques revient au même.

Un dernier rapprochement éclaire à mes yeux d'un jour nouveau un élément obscur d'une réplique de Rosalind en IV.1.134-5 :

Ros. [...] men are April when they woo, December when they wed $[. .$.

J'y vois affleurer une véritable climatologie sexuelle, qui me semble plonger ses racines dans une métaphore grammaticale que l'on trouve expliquée chez Alain :

De ces hommes qui adoptent la grammaire de 
Vénus, certains embrassent de la manière la plus naturelle le genre masculin seulement, d'autres le féminin, d'autres le genre commun, ou bien proche (épicène ?). Il y en a cependant, comme s'ils étaient d'un genre mixte, qui se déclinent avec irrégularité, l'hiver au féminin, l'été au masculin. ${ }^{97}$

La grammatica Veneris n'en a pas fini, semble-t-il, de circuler d'un texte à l'autre.

Ce très rapide et très incomplet parcours grammato-sexuel se donne comme un simple terrain d'intuitions, et une invitation à recherches, çà et là : il ne saurait prétendre à aucun moment à une quelconque exhaustivité. La sexualité du genre et la grammaticalité du sexe requièrent de plus amples explorations, tant il est vrai que leur relation spéculaire est une source vive, où beaucoup puisèrent à la Renaissance. Il faudrait poursuivre le va-et-vient diachronique entre Moyen-Âge et Renaissance dans les pièces de Shakespeare, et l'étendre à d'autres dramaturges: l'on peut penser notamment à Ben Jonson, dont la pièce Epicoene, or The Silent Woman littéralise la confluence métaphorique des deux registres et en fait le principal ressort dramatique, par le nom même du personnage éponyme, tandis que le latin, présent en fragments dans de nombreuses répliques, exhibe la continuité intellectuelle de la pièce avec certains jeux grammaticaux savants. Il faut songer aussi que quelque vingt ans après $A Y L I$, il y aura la petite polémique des pamphlets Hic Mulier / Haec Vir, sur la scène éditoriale londonienne. Les deux œuvres, publiées chacune en 1620 à peu d'intervalle, forment un dyptique grammatical reposant sur deux solécismes ${ }^{98}$. La mise en relief de ces (dés)accords pervers ne saurait montrer plus éloquemment combien le discours conjoint de la grammaire et du sexe est présent en Angleterre à la Renaissance, et qu'il emprunte depuis le haut Moyen-Âge des trajets herméneutiques singuliers. Du côté des dramaturges, et de Shakespeare notamment, gageons qu'il fait surgir une méta-grammaire du genus, qui contribue pour le spectateur au plaisir du texte et de sa représentation. 


\section{NOT E S}

${ }^{1} \mathrm{Je}$ remercie vivement Pierre Iselin (Paris IV) pour les encouragements donnés à ce travail, issu d'une enquête commencée dans le cadre de son séminaire de recherche. Ma gratitude va tout autant à celles et à ceux qui m'ont prodigué leurs références précieuses et parfois inédites, leurs encouragements, et leurs remarques aussi fructueuses qu'amicales: Leo Carruthers (Paris IV), André Crépin (Paris IV), Jean-Paul Debax (Toulouse II), Margaret JonesDavies (Paris IV), Ann Lecercle (Paris X) et Helen Leith Spencer (Exeter College, Oxford), ainsi que Hugo Azérad (Selwyn College, Cambridge), Marc Bonini (Paris IV), Caroline Boucher (EPHE), Jean Du Verger (Paris XI) et Pierre Kapitaniak (Paris IV). Je voudrais exprimer ma profonde reconnaissance à la Société Française Shakespeare, et particulièrement à son président, JeanMarie Maguin (Montpellier III), pour m'avoir offert de présenter ce travail lors du Congrès 2001. L'expression «grammaire des sexes» m'est inspirée de l'ouvrage de Jan M. Ziolkowski, Alan of Lille's Grammar of Sex. The Meaning of Grammar to a Twelfth-Century Intellectual, Speculum Anniversary Monographs 10, Cambridge (Mass.), The Medieval Academy of America, 1985.

${ }^{2}$ Alan Brissenden (éd.), As You Like It, World's Classics, Oxford et New York, Oxford University Press, 1994 (1993), V.1.44. Toutes les citations viennent de cette édition.

${ }^{3}$ Valerie Traub, Desire and Anxiety: Circulations of Sexuality in Shakespearean Drama, Routledge, Kegan Paul, 1992, notamment chapitre 5, p. 117-44.

${ }^{4}$ Gilles Deleuze, Logique du sens, Paris, Minuit, 1969, "Quatrième série, des dualités», p. 37.

${ }^{5}$ Je pense bien entendu, pour ne citer qu'elles, aux démarches théoriques générales de Judith Butler et de Luce Irigaray - je dois à mon ami Hugo Azérad d'avoir découvert l'œuvre de cette dernière. Du côté des critiques shakespeariens, outre les travaux de Valerie Traub citée supra, de William C. Carroll, Louis A. Montrose et Patricia Parker indiqués infra, et les références données à la note suivante, voir notamment Nancy Hayles, «Sexual Disguise in As You Like It and Twelfth Night», Shakespeare Survey 32, 1979, 63-72; Robert Kimbrough, «Androgyny Seen Through Shakespeare's Disguise», Shakespeare Quarterly 33/1, 1982, 17-33; Catherine Belsey, «Disrupting Sexual Difference: Meaning and Gender in the Comedies», in John Drakakis (éd.), Alternative Shakespeares, New Accents, Londres et New York, Methuen, 1986 (1985), 166-90; Barbara J. Bono, «Mixed Gender, Mixed Genre in Shakespeare's As You Like It», in Barbara K. Lewalsky (éd.), Renaissance Genres: Essays on Theory, History, and Interpretation, Harvard, 
Harvard University Press, 1986, 189-212 ; Phyllis Rackin, «Androgyny, Mimesis, and the Marriage of the Boy Heroine on the English Renaissance Stage», PMLA 102/1, 1987, 29-41 ; Juliet Dusinberre, «As Who Liked It ?», Shakespeare Survey 46, 1993, 9-21 et «Women and Boys Playing Shakespeare», in Jean-Paul Debax et Yves Peyré (éds.), As You Like It. Essais critiques, Interlangues Littératures, Toulouse, Presses Universitaires du Mirail, 1998, 11-26. La bibliographie commentée de Pierre Iselin sur le sujet est un guide fort utile: voir "'Call me Ganymede' (1.3.124): The Problem of Identity and Gender. A Review of Criticism», in Pierre Iselin, François Laroque et Jean-Marie Maguin (éds.), William Shakespeare. As You Like It, Paris, Didier Érudition-CNED, 1998, 77-95.

${ }^{6}$ En cela, mon approche se distingue des études d'anthropologie théâtrale, telle celle de Jean E. Howard, «Crossdressing, The Theatre, and Gender Struggle in Early Modern England», Shakespeare Quarterly 39/4, 1988, 418-40 ; de Jan Kott, "The Gender of Rosalind», New Theatre Quarterly 7, 1991, 113-25; de Lesley Anne Soule, «Subverting Rosalind: Cocky Ros in the Forest of Arden», New Theatre Quarterly 7, 1991, 126-36 ; de Grace Tiffany, “That Reason Wonder May Diminish' : As You Like It, Androgyny, and the Theater Wars», The Huntington Library Quarterly, 57/3, 1994, 21339 ; de Henk Gras, «Enchanting Metadrama : Shakespeare and the Use of the Boy Actor in As You Like It», in A. J. Hoenselaars (éd.), Reclamations of Shakespeare, Amsterdam et Atlanta, Rodopi, 1994, 33-55; ou encore celle de Tracey Sedinger, "If sight and shape be true' : The Epistemology of CrossDressing on the London Stage», Shakespeare Quarterly 48/1, 1997, 63-79. I1 va de soi que des éléments d'anthropologie de la scène élisabéthaine nourrissent abondamment les travaux cités à la note précédente.

${ }^{7}$ AYLI, IV.1.184-7 : «Cel. You have simply misused our sex in your love-prate. We must have your doublet and hose plucked over your head, and show the world what the bird hath done to her own nest».

${ }^{8}$ «Is it not a foul bird defiles the own nest?» Cette phrase est citée, mais pas commentée dans ce sens, par Brissenden, op. cit., introduction, p. 12-3. L'édition suivie par Brissenden est celle de Edmund Gosse, The Complete Works of Thomas Lodge, 4 volumes, New York, 1963 (1883); pour cette phrase, voir I, folio 15r. Ceci n'est évidemment qu'un exemple parmi d'autres d'inflexion sexuelle, de Lodge à Shakespeare : pour une comparaison suivie, l'on pourra se reporter à l'édition commode de Rosalynde dans Geoffrey Bullough (éd.), Narrative and Dramatic Sources of Shakespeare, Londres, Routledge and Kegan Paul, 1958, vol. II, p. 158-256. L'article de Marco Minkoff, «What Shakespeare Did To Rosalynde», Shakespeare Jahrbuch 96, 1960, 78-89, esquisse les grandes lignes de l'emprunt.

${ }^{9}$ Heinrich Keil (éd.), Prisciani Grammatici Caesariensis Institutionum Grammaticarum Libri XVIII, ex recensione Martini Hertzii, 2 volumes (I. livres 
I-XII et II. livres XIII-XVII) qui forment la troisième partie de la série Grammatici Latini éditée par Keil, Leipzig, Teubner, 1855 et 1859 ; par commodité, j'abrège en Institutiones le titre de l'édition de Keil. Le passage sur le cas est au livre V, dans la section finale intitulée «De casu» (Keil, Institutiones, I, p. 183-4) : «Casus est declinatio nominis [...], quae fit maxime in fine. nominativus tamen sive rectus [...], quod a generali nomine in specialia cadit, casus appellatur - ut stilum manu cadentem [...] cecidisse possumus dicere...».

${ }^{10} A Y L I$, IV.1.159-61 : «Ros. [...] O, that woman that cannot make her fault her husband's occasion, let her never nurse her child herself, for she will breed it like a fool».

${ }^{11}$ Voir la discussion rapide de toute la scène par William C. Carroll, «The Virgin Not: Language and Sexuality in Shakespeare», Shakespeare Survey 46, 1994, 107-20, repris dans Deborah Barker et Ivo Kamps (éds.), Shakespeare and Gender : A History, Londres et New York, Verso, 1995, 283 301 : p. 285. Voir aussi les remarques de Patricia Parker, dans l'ouvrage mentionné infra.

${ }^{12}$ The Merry Wives of Windsor, IV.1.52-7, in Stanley Wells et Gary Taylor (éds.), William Shakespeare : The Complete Works, Oxford, Clarèndon, 1989 (1988), p. 501.

${ }^{13}$ Eric Partridge, Shakespeare's Bawdy. A Literary and a Psychological Essay and a Comprehensive Glossary, London, Routledge and Kegan Paul, édition revue 1956 (1955), case, p. 84-5; Frankie R. Rubinstein, A Dictionary of Shakespeare's Sexual Puns and their Significance, Londres, Macmillan, 2e édition, 1989 , ne retient case ni dans le dictionnaire ni dans son supplément.

${ }^{14}$ Patricia Parker donne toute sa place au pradigme grammatical, notamment à «case», dans son remarquable ouvrage Shakespeare from the Margins: Language, Culture, Context, Chicago et Londres, University of Chicago Press, 1996 ; voir notamment «Introduction. Edification from the Margins : Language, Culture, Context», p. 1-20 et «"Illegitimate Construction": Translation, Adultery, and Mechanical Reproduction in The Merry Wives of Windsor», p. 116-48.

${ }^{15}$ AYLI, Epilogue, 7-9.

${ }^{16} \mathrm{Je}$ fais bien entendu allusion ici à Richard Wilson, "Like the old Robin Hood' : As You Like It and the Enclosure Riots», Shakespeare Quarterly 43/1, 1992, 1-19, repris dans Richard Wilson, Will Power: Essays on Shakespearean Authority, New York et Londres, Harvester Wheatsheaf, 1993, 63-82 (sur la «shemale», voir p. 73-4).

${ }^{17}$ AYLI, III.2.1-10. Il s'agit bien entendu de l'écorce des arbres qui reçoivent les entailles de l'amoureux. 
${ }^{18}$ Jonathan Goldberg, «Hamlet's Hand», Shakespeare Quarterly 39/3, 1988, 307-27.

${ }^{19}$ Sur la violence stylistique de l'incision, voir Pierre Iselin, «'So quiet and so sweet a style' (2.1.20) : le style de l'églogue et l'éloge du style», in Jean-Paul Debax et Yves Peyré (éds.), As You Like It, op. cit., 93-109.

${ }^{20} \mathrm{La}$ bibliographie des travaux sur la grammaire à la fin de l'Antiquité, au Moyen-Âge et au début de la Renaissance est bien entendu trop riche pour que j'y fasse ici plus que des références choisies, en prise avec mon propos. Pour un premier guide, l'on pourra se reporter, par exemple, aux articles «grammaire française médiévale» et «grammaire latine médiévale» du Dictionnaire des lettres françaises. Le Moyen-Âge, édition revue par G. Hasenohr et M. Zink, Paris, Fayard, 1994, respectivement p. 564-5 et p. 565-72. Pour le contexte de la Renaissance continentale et anglaise, outre les travaux spécifiques de T, W. Baldwin et J. W. Binns cités infra, voir notamment G. A. Padley, Grammatical Theory in Western Europe, 1500-1700. The Latin Tradition, Cambridge, Cambridge University Press, 1976, et Konrad Koerner (éd.), Vivian Salmon. Language and Society in Early Modern England. Selected Essays 198194, Amsterdam et Philadelphie, John Benjamins Publishing Company, 1996.

${ }^{21}$ Louis Holtz (éd.), Donat et la tradition de l'enseignement grammatical. Étude et édition critique, Paris, CNRS, 1981.

${ }^{22}$ C. S. Lewis, The Discarded Image. An Introduction to Medieval and Renaissance Literature, Canto, Cambridge, Cambridge University Press, 1995 (1964), VII, I, p. 188 : «One's well-thumbed manuscript of Donatus was one's donat or donet, which by an easy transference comes to mean the 'primer' or 'rudiments' of any subject whatever». Lewis cite une occurrence de «donet» en ce sens élargi dans Piers Plowman, version C, passus VII.

${ }^{23}$ Holtz, Donat..., p. 431.

${ }^{24}$ Sur les commentaires sur Priscien au Moyen-Âge, voir notamment le premier de deux articles pionniers de R. W. Hunt, «Studies on Priscian in the Eleventh and Twelfth Centuries», Mediaeval and Renaissance Studies 1, 1941 43, 194-231.

25 Priscien, Institutiones, II, XVII-XVIU, «De constructione sive ordinatione partium orationis inter se». On notera que le livre XVI s'intitule «De coniunctione».

${ }^{26}$ Il m'est impossible ici de débrouiller les pistes nombreuses qu'offre l'enchevêtrement des éditions, rééditions et traductions à collaborations diverses. Un premier guide sur les travaux de William Lyly, bien qu'ancien, demeure l'étude solide de Vincent J. Flynn, «The Grammatical Writings of William Lily, ?1468-?1523», The Papers of the Bibliographical Society of America 37, 1943, 85-113 (article issu d'une thèse de l'Université de Chicago, 1939). L'ouvrage double intégra l'Aeditio de John Colet et la substance de plusieurs traités de William Lyly (Rudimenta Grammatices, 1509; De 
Constructione, 1513 ; De generibus nominum, 1520). Outre Flynn, certains des faits rapportés dans ce paragraphe et cette note viennent de la synthèse de James W. Binns, Intellectual Culture in Elizabethan and Jacobean England. The Latin Writings of the Age, ARCA 24 (Classical and Medieval Texts, Papers and Monographs), Leeds, Francis Cairns, 1990, chapitre 16 «Latin Teaching and Latinity», p. 291-306 (notamment p. 293).

${ }^{27} \mathrm{Je}$ cite d'après une réédition (ultérieure à $A Y L D$ ) que j'ai consultée : William Lyly et John Colet, A Short Introduction of Grammar, generally to be vsed: compiled and set forth for the bringing vp of all those that intend to attaine the knowledge of the latine tongue (Brevissima Institutio), 1e partie, London, John Norton, 1607 (STC 16848), folio A8 : «Genders of Nounes be seuen: the masculine, the Feminine, the Neuter, the common of two, the common of three, the Doubtful and the Epicene. The Masculine Gender is declined with this Article Hic : as Hic Vir, A Man. The Feminine Gender is declined with this Article Hæc : as Hæc mulier, A Woman. The Neuter Gender is declined with this Article Hoc : as Hoc saxum, A Stone. The Common of two is declined with Hic, and Hæc : as Hic \& hæc Parens, a father or mother. The Common of three is declined with Hic, hæc and hoc : as Hic hæc \& hoc Foelix, Happy. The Doubtful gender is declined with Hic or hæc: as Hic vel hæc dies a Day. The Epicene gender is declined with one article, and under that one article both kinds be signified: as Hic passer, a Sparrow : Hæc aquila, an Eagle, both he and shee». On comparera l'argumentaire et les exemples avec Donat, Ars Maior II, 4.5 (Holtz, p. 619 21).

${ }^{28}$ Lyly fut à Magdalen College, Oxford (BA 1573, MA 1575) et Marlowe à Corpus Christi, Cambridge (BA 1583-4, MA 1587).

${ }^{29} \mathrm{Je}$ n'insiste pas sur un tableau déjà bien campé pour l'ensemble par T. W. Baldwin dans son monumental William Shakspere's Small Latine \& Lesse Greeke, 2 vols., Urbana, University of Illinois Press, 1944. On se reportera notamment à la troisième partie foisonnante, «Shakspere's Grammar School Training», et à l'Annexe II (vol. 2), «Formation of the Authorized Grammar», p. 690-701. Binns, op. cit., p. 291-2, reprend les conclusions de Baldwin.

${ }^{30}$ Dans une correspondance personnelle, Jean-Paul Debax me renseigne fort obligeamment sur l'expression latine a per se, d'une «utilisation assez voisine» d'ipse, et qui a une «fonction de nomination d'un personnage, avec effet parodique». Parmi les références qu'il me communique, je n'ai eu le loisir de me reporter qu'à Ane Satyre of the Thrie Estaitis de Sir David Lindsay (1552), dans l'édition de Roderick Lyall, Canongate Classics 18, Édimbourg, Canongate, 1994 (1989). Dans une scène où les Vices Dissait, Falset et Flatterie font assaut d'hyperboles auprès de Rex Humanitas, Dissait conclut une réplique de la sorte (v. 912-3) : «Quhairto, sir, be the Trinitie, / Ye are ane verie A-per-sie». L'éditeur glose A-per-sie par «paragon» (p. 32). C'est aussi 
Jean-Paul Debax qui a attiré mon attention sur le lien entre AYLI V.1.42-5 et III.3.2. Qu'il trouve donc ici l'expression de ma vive gratitude.

${ }^{31}$ Le commentaire sur ipse chez Pierre Hélie et dans la Glosule anonyme a été publié à titre d'exemple par Hunt, «Studies on Priscian...», p. 204.

${ }^{32}$ Priscien, Institutiones, XVII (Keil, p. 206-7): «Pronomen ipse, tribus aptissime, ut supra diximus, coniungitur personis. itaque Apollonius $\varepsilon \pi \imath \tau \alpha \gamma \mu \alpha \tau \iota \kappa o v$ hoc vocat, id est appositivum, quod aliis pronominibus apponitur, ut ipse ego, vel ego ipse, tu ipse, ille ipse. et quamvis inveniantur etiam alia pronomina figurate sic coniuncta per diversas personas, ut $e g o$ ille, tu ille, hic ille [...] non tamen; quomodo ipse sine alio pronomine possunt primae et secundae personae verbis adiungi, ut ipse facio, ipse facis [...] alias autem voces tertiae pronominum personae per se sic verbis primae et secundae personae non possumus copulare. nemo enim dicit ille facio et ille facis, nisi addas et pronomina primam et secundam demonstrantia personam [...] sed ille ego vel ille tu cum dicimus, relationem significamus antecedentis cognitionis. ipse ego vero discretionem, id est ipse ego per me et non alius».

${ }^{33}$ Outre la table à la fin du volume II de l'édition de Keil, consulter Cirilo García Román, Marco A. Gutíerrez Galindo et María del Carmen Díaz de Alda Carlos (éds.), Prisciani Institutionum Grammaticalium Librorum XVI et XVIII Indices et Concordantiae, 2 volumes (I. A-O et II. P-X, verba graeca), Hildesheim, Zürich, New York, Olms-Weidmann, 1999.

${ }^{34}$ Ernst R. Curtius, La littérature européenne et le Moyen-âge latin, traduction française par Jean Bréjoux, Paris, Presses Universitaires de France, 1956, Excursus 3, «Les expressions grammaticales et rhétoriques dans les métaphores», p. 512-4.

${ }^{35}$ John A. Alford, «The Grammatical Metaphor : A Survey of Its Use in the Middle Ages», Speculum 57, 1982, 728-60 ; p. 729: «[...] the Latin culture of the Middle Ages was an ideal context in which the metaphorical basis of grammatical terminology [...] could be recognized and exploited». J. Ziolkowski, Alan of Lille's Grammar of Sex...., le rejoint pleinement dans sa conclusion, p. 141 : «Grammatical metaphors [...] are especially likely to appear when, as is the case in Latin, the terminology of grammar contains roots which are metaphorically suggestive».

${ }^{36}$ Alford, op. cit., p. 736-50, s'appuie sur le Metalogicon pour rappeler que la pensée médiévale faisait équivaloir processus grammatical et naturel. On peut reprocher cependant à sa brillante analyse d'introduire une distinction excessive entre les métaphores générées par la terminologie grammaticale et celles issues de la théorie grammaticale.

${ }^{37}$ On pourra consulter l'édition bilingue du tome 3 de L'ouvre d'Anselme de Cantorbéry, sous la direction de Michel Corbin, s. j. : L'Incarnation $d u$ Verbe. Pourquoi un Dieu-homme, introduction, traduction et notes de Michel Corbin et Alain Galonnier, Paris, Cerf, 1988. 
${ }^{38}$ Jean de Salisbury, Metalogicon, I.15 (PL 199, col. 843). Ces expressions sont citées par Valerie Allen, "Middle-Aged Bodies. A Review of Dolores Warwick Frese and Katherine O'Brien O'Keeffe (eds.), The Book and The Body», Envoi (A Review Journal of Medieval Literature), 7/1, 1998, p. 1 22: 14-5.

${ }^{39}$ Peter G. Walsh, «Alan of Lille as a Renaissance Figure», Renaissance and Renewal in Christian History 14, 1977, 117-35.

${ }^{40}$ James Willis (éd.), Martianus Capella, Bibliotheca Scriptorum Graecorum et Romanorum, Leipzig, Teubner, 1983; le De Nuptiis Philologiae et Mercurii est aux pages 1-386 (voir Livre III, «De Arte Grammatica», p. 58105).

${ }^{41}$ Sur ce sujet connexe à celui de mon enquête, je remercie vivement Leo Carruthers de m'avoir permis de lire sa communication inédite, «Identité sexuelle et genre grammatical dans la représentation allégorique des Vices et des Vertus», présentée à l'atelier médieval du 31e Congrès de la Société des Anglicistes de l'Enseignement Supérieur, Aix-en-Provence, 1991, sur le thème «Identité et Différence».

${ }^{42}$ Nikolaus M. Häring (éd.), «Alan of Lille, De Planctu Naturae», Studi Medievali 19, Centro Italiano di Studi sull'Alto Medioevo, Spoleto, 1978, 797-879. Sur la date de composition, voir p. 797, note 1 , et James J. Sheridan, Alan of Lille. The Plaint of Nature, Toronto, Pontifical Institute of Mediaeval Studies, 1980, Introduction, p. 31-5. Toutes les citations du De Planctu suivent l'édition de Häring.

${ }^{43}$ Jan Ziolkowski, Alan of Lille's Grammar of Sex..., 1985, "Ch. 4. Theology and the Limitations of Grammar», p. 127 : «Like many other scholastic theologians, Alan of Lille owes an unspoken debt to Anselm and his grammar of God. Yet Alan is no more indebted to Anselm than he is to many other thinkers; an eclectic and a synthesizer by nature, Alan is open to any source that provides elements suitable to his theory of language and grammar».

${ }^{44}$ A. Leupin, Barbarolexis. Medieval Writing and Sexuality, traduit par Kate M. Cooper, Cambridge (Mass.), London, Harvard University Press, 1989, «Ch. 3. The Hermaphrodite: Alan of Lille's De Planctu Naturae», p. 59: le De Planctu représente «one of the most significant attempts in the Middle Ages to account for all the inferences of this period's poetics». Sur la théologie et la poétique, voir J. Huizinga, Über die Verknüpfung des Poetischen mit dem Theologischen bei Alanus de Insulis, Amsterdam, Med. Akad., 1932. Sur la rhétorique et la poétique, consulter Guy Raynaud de Lage, Alain de Lille, poète du XIlème siècle, Paris, Vrin, 1951 ; Winthrop Wetherbee, «The Function of Poetry in the De Planctu Naturae of Alain de Lille», Traditio 25, 1969, 87-125 ; Alain Michel, «Rhétorique, poétique et nature chez Alain de Lille», in Alain de Lille, Gautier de Châtillon, Jakemart Giélée et leur temps. Actes du colloque de Lille, octobre 1978, éd. H. Roussel et F. Suard, actes 
publiés en tant que $\mathrm{n}^{\circ} 2$ de Bien dire et bien aprandre (revue de l'Université de Lille), 1979, 113-24.

${ }^{45}$ Dans une excellente mise en contexte du poème, Richard Hamilton Green, «Alan of Lille's De Planctu Naturae», Speculum 31, 1956, 649-74, évoque p. 649 «a poetic method in which surface diversity is not incompatible with inner unity».

${ }^{46}$ Sur Guillaume de Conches et pour une réflexion générale sur l'integumentum, voir le remarquable article d'Édouard Jauneau, «L'usage de la notion d'integumentum à travers les gloses de Guillaume de Conches», Archives d'Histoire doctrinale et littéraire du Moyen-Âge 24, 1957, 35-100. 7) :

${ }^{47}$ Alain de Lille, De Planctu Naturae, I Metrum 5-24 (Häring, p. 806-

[...] Venus in Venerem pugnans illos facit illas

[Et] sui magica deuirat arte uiros.

[...]

Actiui generis sexus se turpiter horret

Sic in passiuum degenerare genus.

Femina uir factus sexus denigrat honorem,

Ars magice Veneris hermafroditat eum.

Predicat et subicit, fit duplex terminus idem.

Gramatice leges ampliat ille nimis.

Se negat esse uirum Nature, factus in arte

Barbarus. Ars illi non placet, immo tropus.

Non tamen ista tropus poterit translatio dici.

In uicium melius ista figura cadit.

${ }^{48}$ C'est le sens de la conclusion de Ziolkowski, Alan of Lille's Grammar of Sex..., p. 141-4: «[...] the grammatical metaphors pose questions beyond that of the disjunction between the rules of grammar and sex. The vividness of their grammatical coloring raises the possibility that Lady Nature is more interested in grammar than in sexuality. [...] The incessant mentions of grammar betray Alan's didactic intentions in writing his allegory. [...] the De Planctu Naturae gives poetic form to Alan's teachings on grammar, reading, and speaking about God».

${ }^{49}$ Sur l'importance du prosimètre à la fin de l'Antiquité et au Moyen-Âge, voir Caroline D. Eckhardt, «The Medieval Prosimetrum Genre (from Boethius to Boece)», Genre, 16/1, 1983, 21-38, et Jan Ziolkowski, «The Prosimetrum in the Classical Tradition», in Joseph Harris et Karl Reichl (éds.), Prosimetrum: Crosscultural Perspectives on Narrative in Prose and Verse, Cambridge, D. S. Brewer, 1997, 45-61.

${ }^{50}$ Sheridan, op.cit., passim et Raynaud de Lage, op. cit., p. 153, donnent l'architecture de chaque metrum : ainsi les metra 1, 3 et 5 sont des distiques élégiaques, le metrum 2 des ascépiades mineurs (ainsi peut-être que le metrum 6, mais voir Raynaud de Lage, p. 104 n. 233), le metrum 4 est en 
strophes sapphiques, les metra 7 et 9 sont des hexamètres dactyliques, et le metrum 8 est alcaïque.

${ }^{51}$ Raynaud de Lage, Alain de Lille..., p. 105 et p. 152-3 (brève analyse des types de cursus présents dans la prose d'Alain).

${ }^{52}$ Raynaud de Lage, Alain de Lille..., p. 103-9; Eckhardt, «The Medieval Prosimetrum Genre...», p. 23-30.

${ }^{53}$ Les manuscrits du De Planctu Naturae connurent une diffusion large dès la fin du XIIe siècle ; voir par exemple C. H. Talbot, «A List of Cistercian Manuscripts in Great Britain», Traditio 8, 1952, 402-17. Notons que les milieux monastiques constituèrent un terrain privilégié pour la dissémination de l'œuvre d'Alain, étant donné l'inflexion théologique (et potentiellement morale) du De Planctu.

${ }^{54}$ R. Lenzen (éd.), "Altercatio Ganimedis et Hêlenae : Kritische Edition mit Kommentar», Mittellateinisches Jahrbuch 7, 1972, 161-86. Pour m'aider dans ma traduction j'ai consulté la traduction anglaise établie par John Boswell, Christianity, Social Tolerance, and Homosexuality, Chicago, Chicago University Press, 1980, «Appendix Two», p. 381-9. Une autre figure dans Th. Stehling, Medieval Latin Poems of Male Love and Friendship, Garland Library of Medieval Literature (Series A.7), New York, Garland Publishing, 1984.

${ }^{55}$ Pour un panorama général de ces textes, se reporter par exemple à nouveau à Alford, op. cit., et voir Jan M. Ziolkowski, «Obscenity in the Latin Grammatical and Rhetorical Tradition», in Jan M. Ziolkowski (éd.), Obscenity : Social Control and Artistic Creation in the European Middle Ages, Cultures, Beliefs and Traditions 4, Leyde, New York, Cologne, Brill, 1998, p. $41-59$.

${ }^{56}$ Voir par exemple une cansó anonyme du XIIIe siècle, et deux coblas du Bort del Rei d'Aragon et de Rostanh Berenguier de Marselha (début du XIVe siècle), reproduits dans l'agréable anthologie bilingue de Pierre Bec, Burlesque et obscénité chez les troubadours. Le contre-texte au Moyen-Âge, «MoyenÂge», Paris, Stock, 1984, p. 125-30. Je remercie mon ami Jean Du Verger de m'avoir fait découvrir ces textes.

${ }^{57}$ Charles d'Orléans, rondel 83, Ballades et Rondeaux, éd. J.-C. Mühlethaler, Lettres Gothiques, Paris, Livre de Poche ( ${ }^{\circ} 4531$ ), 1992, p. 464. Mon attention a été portée sur ce rondel par la citation qui en est faite par André Crépin, Deux mille ans de langue anglaise, Nathan Université, collection «fac. langues étrangères» (série «linguistique»), Paris, Nathan, 1994, ch. 10, $\S 10.1 .0$, p. 71 .

${ }^{58}$ Voir Elizabeth B. Keiser, Courtly Desire and Medieval Homophobia. The Legitimation of Sexual Pleasure in Cleanness and Its Contexts, New Haven, London, Yale University Press, 1997, notamment chapitre 3 «Educating Love: Nature as Sexual Norm in Cleanness and Alain's Complaint» et 
chapitre 5 «Revising the Complaint : Desire in the Roman as Context for Cleanness».

${ }^{59}$ Plusieurs travaux existent d'ailleurs déjà à ce sujet : voir par exemple Maureen Quilligan, «Words and Sex: The Language of Allegory in the De Planctu Naturae, the Roman de la Rose, and Book III of The Faerie Queene», Allegorica 2, 1977, 195-216, et l'article de 1981 cité infra ; Lisa J. Kiser, «Alain de Lille, Jean de Meun, and Chaucer : Ecofeminism and Some Medieval Lady Natures», in Piero Boitani et Anna Torti (éds.), Mediaevalitas : Reading the Middle Ages, The J. A. W. Bennett Memorial Lectures. Ninth Series, Cambridge, D. S. Brewer, 1996, 1-14.

${ }^{60}$ A. V. C. Schmidt (éd.), Piers Plowman. A Parallel-Text Edition of the $A, B, C$ and $Z$ Versions. Volume I. Text, Londres, New York, Longman, 1995, C.III.328-405, p. 125-31.

${ }^{61}$ Sur la conjonction «si» comme principe structurant d'AYLI, voir Marie-Thérèse Jones-Davies, «Le monde du 'si' : idéologies incertaines dans Comme il vous plaira», in Théâtre et idéologies: Marlowe, Skakespeare. Actes du Congrès de la Société Française Shakespeare (1981), Paris, Touzot, 1982, 51-67.

${ }^{62}$ Omettant par commodité les travaux de référence généraux sur Piers Plowman, je renvoie seulement aux principaux commentaires portant précisément sur le passage cité : A. V. C. Schmidt, «Direct and Indirect Relation», Notes and Queries 214, 1969, 285-6; Margaret Amassian et James Sadowsky, «Mede and Mercede. A Study of the Grammatical Metaphor in Piers Plowman C.IV [erreur pour III].335-409», Neuphilologische Mitteilungen 72, 1971 , 457-76 ; M. N. K. Mander, «Grammatical Analogy in Langland and Alan of Lille», Notes and Queries, 1979, 501-4; Robert Adams, «Mede and Mercede: the Evolution of the Economics of Grace in the Piers Plowman B and C Versions», in E. D. Kennedy, R. Waldron et J. S. Wittig (éds.), Medieval English Studies Presented to George Kane, Cambridge, D. S. Brewer, 1988, 217-32.

${ }^{63} \mathrm{Le}$ remarquable article d'Anne Middleton, «Two Infinites : Grammatical Metaphor in Piers Plowman», English Literary History 39/2, 1972, 169-88, fait ainsi amplement référence à Priscien.

${ }^{64}$ D'après le Short Title Catalogue, la seule ouvre d'Alain éditée est son traité de géométrie, le De Parabolis. Il faudrait chercher du côté des publications continentales à la Renaissance et de leur diffusion en Angleterre, pour vérifier l'éventuelle circulation du De Planctu sous forme d'imprimé.

${ }^{65}$ Maureen Quilligan estime que plusieurs manuscrits du De Planctu ont pu être accessibles à Edmund Spenser. Voir son article «Alanus de Insulis», in A. C. Hamilton et al. (éd.), The Spenser Encyclopedia, Toronto, Buffalo, Routledge et Londres, University of Toronto Press, 1990, p. 12. Cette affirmation se fonde sur un travail antérieur de Quilligan. 
${ }^{66}$ Parmi les nombreux travaux récents, je me contenterai de signaler le bon recueil d'articles rassemblés par Theresa M. Krier (éd.), Refiguring Chaucer in the Renaissance, Gainesville, University Press of Florida, 1998.

${ }^{67}$ The Parliament of Fowls, in Larry D. Benson (éd.), The Riverside Chaucer, Oxford, Oxford University Press, 3e édition, 1988 (1987), p. 393-4 et notes p. 994-1002. On consultera aussi l'édition et les notes de Derek S. Brewer (éd.), The Parlement of Foulys, Old and Middle English Texts, Manchester, Manchester University Press, 1985 (1972 ; d'après l'édition originale par Thomas Nelson and Sons Ltd, 1960).

${ }^{68}$ Les éditions du Roman ont pour texte de base des manuscrits différents. Je suis l'édition et la numérotation des vers d'Armand Strubel (éd.), Guillaume de Lorris et Jean de Meun. Le Roman de la Rose, Lettres gothiques 4533, Paris, Livre de poche, 1992.

${ }^{69}$ De Planctu, I Prosa 138-47 (Häring, p. 813-4).

${ }^{70}$ Le terme «vicarye» avait été repris par Jean de Meun (voir notamment Roman, v. 16786 et 19511, en doublet avec «conestable»); il illustre parfaitement l'empilement des sources et des autorités derrière le poème de Chaucer.

${ }^{71} \mathrm{Je}$ me réfère bien entendu à l'article important de Maureen Quilligan, «Allegory, Allegoresis, and the Deallegorization of Language: The Roman de la rose, the De planctu naturae, and the Parlement of Foules», in Morton M. Bloomfield (éd.), Allegory, Myth, and Symbol, Harvard English Studies 9, Cambridge (Mass.) et Londres, Harvard University Press, 1981, 163-86. Je ne rends pas justice en si peu de mots à la richesse de ce travail (sur la différence entre allégorie et allegoresis et sur l'éthique de l'allégorie, notamment, qui reprennent les propositions de son ouvrage The Language of Allegory: Defining the Genre, Ithaca, Cornell University Press, 1979), tout en exprimant mes réserves sur certains points de sa démarche : par exemple, p. 177, elle me semble mal interpréter le jugement de D. Brewer sur ce que Chaucer doit à Alain (op. cit., introduction, notamment p. 43).

${ }^{72}$ On confrontera avec grand profit les approches de Quilligan, op. cit., 1981 et de Lisa J. Kiser, op. cit.

73 A. C. Hamilton (éd.), The Faerie Queene, Longman Annotated English Poets, London, New York, Longman, 1995 (1977), VII.7.1-10 (p. 724-5).

${ }^{74}$ Philip Henderson (éd.), The Shepherd's Calendar and Other Poems, Everyman's Library n879, London, Dent, 1932, réimp. 1962. Voir notamment la 2e Eclogue («February») et la $12 \mathrm{e}$ («December»).

${ }^{75} \mathrm{~L}$ 'autre mention de «Dan Chaucer» est en IV.2.32 (Hamilton, p. 439).

${ }^{76} \mathrm{Se}$ reporter à l'introduction et à l'édition par Lothar Cerny, Leonard Hutton (?). Bellum Grammaticale Sive Nominum Verborumque Discordia Civilis (suivie de Thibaldus Sive Vindictae Ingenium de Thomas Snelling), 
Renaissance Latin Drama in England 12, Hildesheim et New York, Georg Olms, 1982, p. 1-13 (introduction, avec un résumé de l'intrigue p. 7-12) et facsimile, d'après l'édition de 1635 (la pièce elle-même, hors l'appareil des préfaces et dédicaces, fait 66 pages dans son édition originale). La source est une allégorie en prose à succès de l'humaniste italien Andrea Guarna, Bellum Grammaticale, publiée en 1511.

${ }^{77}$ Bellum grammaticale, fac-simile, p. 66.

${ }^{78}$ J. W. Binns, op. cit., chapitre 8 (sur le théâtre anglo-latin), rappelle (p. 140 et p. 490 note 11) l'allusion probable à la pièce (aujourd'hui presque entièrement perdue) Caesar interfectus de Richard Edes, dans Hamlet, III.2.96101.

${ }^{79}$ John Lyly, Mother Bombie, in William Tydeman (éd.), Four Tudor Comedies, Penguin Classics, Londres, Penguin, 1984, p. 291-371, et notes attenantes, p. 407-26. (Le passage commenté, I.3.329-72 est p. 309-10).

${ }^{80}$ T. W. Baldwin, op. cit., I, chapitre XXVIII, p. 641-81 ; J. W. Binns, op. cit., chapitre 7 (sur les éditions anglaises et les traductions en anglais de la poésie néo-latine continentale), p. 114-5, et notes attenantes.

${ }^{81}$ Dans l'infime partie de la critique shakespearienne que j'ai explorée, je n'ai guère trouvé à ce jour de travail qui fasse état d'un rapprochement entre l'œuvre d'Alain de Lille et celle de Shakespeare (qu'il s'agisse ou non d'AYLI), si ce n'est dans l'ouvrage de Patricia Parker, op. cit., 1996, dans un chapitre fort stimulant, "Rude Mechanicals": A Midsummer Night's Dream and Shakespearean Joinery», p. 83-115 (voir p. 91 et p. 94 , et note 26 p. 307); voir aussi le début du chapitre 4, op. cit., et la note 8 p. 315 .

${ }^{82}$ Sur le détail des deux leçons, voir Brissenden, op. cit., apparat critique sur le vers 109, et note explicative, p. 222. La confusion éventuelle entre les deux lectures est une fois encore une affaire de main: Brissenden rappelle que hir et his pouvaient aisément se ressembler dans les écritures élisabétaines héritées, bien entendu, des nombreuses cursives, notamment les variétés de bâtarde anglicana, de la fin du Moyen-Âge en Angleterre.

${ }^{83}$ François Rigolot, «Gender vs. Sex Difference in Louise Labé's Grammar», in Margaret W. Ferguson, Maureen Quilligan et Nancy J. Vickers (éds.), Rewriting the Renaissance. The Discourses of Sexual Difference in Early Modern Europe, Chicago, London, University of Chicago Press, 1986, 287 98. Dans cet article très stimulant, qui explore le même type de leçons éditoriales dans les œuvres de Louise Labé, Rigolot écrit (p. 291): «it is tempting to identify this ungrammatical switch of genders not as a typological error but as a hermeneutic problem, closely related to the intentionality of the text».

${ }^{84}$ De Planctu, V Prosa 54-7 (Häring, p. 846) : «[...] Si enim genus masculinum genus consimile [...] deposcat [...] nulla figure honestate illa constructionis iunctura uicium poterit excusare sed inexcusabili soloecismi 
monstruositate turpabitur (en effet, si le genre masculin appelle à lui un genre tout semblable au sien $[\ldots]$, aucune union ne pourra excuser le défaut de la construction, comme s'il s'agissait d'une simple figure [de style]; au contraire, elle sera entachée de la honte d'un solécisme inexcusable et monstrueux)».

${ }^{85}$ Louis A. Montrose, "The Place of a Brother' in As You Like It : Social Process and Comic Form», Shakespeare Quarterly 32, 1981, 28-54, repris dans Ivo Kamps (éd.), Materialist Shakespeare. A History, London, New York, Verso, 1995, 39-70 (p. 39) : «Rosalind's union with Orlando entails the weakening of her ties to her natural father and to a cousin who has been closer to her than a sister; Orlando's union with Rosalind entails the strengthening of his ties to his elder brother and to a lord who becomes his patron. Orlando's atonements with other men - a natural brother, a social father - precede his atonement with Rosalind. [...] The atonement of earthly things celebrated in Hymen's wedding song incorporates man and woman within a process that reunites man with man».

${ }^{86}$ Osons proposer une structure profonde pour ces vers : $\{X(Y$ ?)'s hand / $\boldsymbol{B E}$ joined with $/ Y(X$ ?)'s $\}$ et $\{Y(X$ ?)'s heart / BE within $/ X(Y$ ?)'s bosom $\}$.

${ }^{87}$ A YLI, V.4.120-41.

${ }^{88}$ De Planctu, IV Prosa 55-9 (Häring, p. 834) : «Humanum namque genus, a sua generositate degenerans, in constructione generum barbarizans, Venereas regulas inuertendo nimis irregulari utitur mataplasmo. Sic homo, Venere tiresiatus anomala, directam predicationem per compositionem inordinate conuertit. A Veneris ergo orthographia deuiando recedens sophista falsigraphus inuenitur».

${ }^{89}$ De l'image et de l'usage des couleurs de rhétorique, héritées de l'Antiquité et retravaillées dans les traités médiévaux de poétique (principalement, Matthieu de Vendôme, Ars Versificatoria, avant 1175, Geoffroi de Vinsauf, Poetria Nova, ca. 1210, et Jean de Garlande, Poetria, première moitié du XIIle siècle), le Franklin (riche propriétaire terrien) de Chaucer formule une critique éloquente, tout en exhibant encore ce qui motive le rapprochement entre les deux registres:

Colours ne knowe I none, withouten drede,

But swiche colours as growen in the mede,

Or elles swiche as men dye or peynte.

Colours of rhetoryk been to me queynte ;

My spirit feeleth noght of swich mateere.

The Prologe of the Frankeleyn's Tale, F 723-7 (The Riverside Chaucer, op. cit., p. 178). Ce passage est cité par Charles S. Baldwin, Medieval Rhetoric and Poetic (to 1400), Gloucester, Mass., Peter Smith, 1959 (1928), p. 290 .

${ }^{90}$ Sur la question des actes de référence et des jeux de langage, voir Keir Elam, Shakespeare's Universe of Discourse. Language-Games in the Comedies, 
Cambridge, Cambridge University Press, 1984, notamment l'introduction, p. 1-32.

${ }^{91}$ De Planctu, I Metrum 31-2 (Häring, p. 807) : «C'est ainsi qu'avec le pied [mètre] dactylique, la manière de Vénus. ïambise mal [tient mal l'iambe] / Là où une syllabe longue n'en souffre pas une brève». Le trait métaphorique repose sur le fait que l'ïambe est bien entendu composé d'une syllabe brève suivie d'une longue.

${ }^{92}$ De Planctu, I Prosa 21-5 (Häring, p. 809) : «Dentes quadam sui coloris consonantia eboris faciem exemplabant. Genarum ignis purpureus, rosarum succensus murice, dulci flamma faciem amicabat. Candore namque graciali amicam sentiebat temperiem, purpura uultus sindoni maritata».

${ }^{93}$ AYLI, I.1.18-20 :

Ami. [...] Happy, is your grace

That can translate the stubbornness of fortune

Into so quiet and so sweet a style.

${ }^{94}$ De Planctu, V Prosa 142-4 (Häring, p. 849) : «[...] se gramaticis constructionibus destruens, dialecticis conuersionibus inuertens, rethoricis coloribus decolorans, suam artem in figuram, figuram in uicium transferebat $[\ldots] »$.

${ }^{95}$ On note le commentaire insistant sur la main de Phoebe de la part de Rosalind-Ganymede en IV.3.25-8 :

Ros. I saw her hand. She has a leathern hand,

A free-stone coloured hand. I did verily think

That her old gloves were on ; but 'twas her hands.

${ }^{96}$ AYLI, IV.3.29-37.

She has a housewife's hand - but that's no matter.

${ }^{97}$ De Planctu, IV Prosa 83-7 (Häring, p. 835) : «Eorum siquidem hominum qui Veneris profitentur gramaticam, alii solummodo masculinum, alii femininum, alii commune, siue genus promiscuum, familiariter amplexantur. Quidam vero, quasi etherocliti genere, per hyemem in feminino, per estatem in masculino genere, irregulariter declinantur».

${ }^{98}$ Muld Sacke: or The Apologie of Hic Mulier: To the late Declamation against her. Exprest in a short Exclamation, Londres, imprimé pour Richard Merchen, 1620, et sa réponse, HÆCC-VIR: or The Womanish-Man : Being an Answere to a late Booke intituled Hic-Mulier. Exprest in a briefe Dialogue betweene Hæc-vir the Womanish-Man, and Hic-Mulier the Man-Woman, Londres, imprimé pour I. T., 1620. 